\title{
The Ethics of Identity and World Christianity
}

\section{David Tonghou Ngong ${ }^{1}$}

\begin{abstract}
In describing the nature of Christian ethics in America before and after some recent interventions, Stanley Hauerwas notes that the subject of Christian ethics in America was and is America rather than the Church. He finds this disturbing because it seems to marginalize distinctively Christian moral formations. This critique raises the question of the nature of Christian identity. What should Christian identity in America, Asia, Africa, Europe, Latin America, etc. look like? This question becomes especially urgent with the rise of world Christianity which takes for granted the idea that Christians who live in different contexts perform the Christian faith differently because of said context. This paper argues that while the variety of Christian identities that exist in world Christianity is made necessary by the context in which world Christianity developed, when taken to extremes, it may, among other things, lead to ecclesial apartheid.
\end{abstract}

Key Words: world Christianity, translation, Christian identity, postcolony, racism

\section{Introduction}

In describing the nature of Christian ethics in America before and after the intervention of ethicists like John Howard Yoder, Stanley Hauerwas (2015:74) notes that the subject matter of "Christian ethics in America was first and foremost America," especially seen through the prism of liberal democracy. Seeing America as the subject matter of Christian ethics, Hauerwas avers, left Christian ethics with nothing interesting to say because the Christian cause became coterminous with the promotion of liberal democracy. Rather than promoting liberal democracy which is characterized by a moral vacuum, Hauerwas (2015:182) insists, Christian ethics should focus on the centrality of the church in forming people who live virtuous lives that would fill "the moral emptiness at the heart of liberalism." Read against the background of H. Richard Niebuhr's "enduring problem" of the relationship between the Christian faith and other cultures (2001:1-44), one would see that Hauerwas'

1 David Tonghou Ngong is originally from Cameroon, Africa, and currently Associate Professor of Religion and Theology at Stillman College, Tuscaloosa, Alabama, USA. He is editor of A New History of African Christian Thought (Routledge, 2017). He can be reached at Dngong@stillman.edu or dvdngng@ yahoo.co.uk.

2 Responding to the charge that liberal democracy is morally vacuous is beyond the scope of this paper but it should simply be noted here that the claim, like many of the claims Hauerwas makes, is a highly contentious. 
claim raises the question of Christian identity, specifically Christian moral identity, in the context of America's liberal democratic values. More specifically, Hauerwas here raises the question of how Christian identity should be defined in the context of America: should Christian identity in America be defined by America's vision of itself as a liberal democracy or by the vision of the peace of God contained in the gospel of Jesus Christ and proclaimed by the church? Is it legitimate for both visions (America's liberal democratic vision and the church's vision of peace) to form Christian identity? In other words, should followers of Jesus Christ be Christians first and then Americans second, Americans first and then Christians second or can they be both at the same time? Is it possible to be both at once? If so, how? If not, why not?

These questions will not be answered in this paper but it is important to note that they gain added significance in the context of world Christianity where Christians are raising these issues in various regions around the world. In the Asian contexts Christians are asking about how Asian (or Chinese or Indian) Christian identity ought to be (Kim 2008, Rajkumar 2015). Should it be defined by specifically Asian cultural commitments or by specifically Christian commitments or by both? What of African Christian identity? Should African Christian identity be defined by African cultural commitments, Christian commitments, or both? In other words, what should be the relationship between Christian values and local values (Schreiter 1985, 1997)? These questions become even more complex when one includes the various diasporas around the world, which have led to the development of many Christian communities far away from what their members would consider home (Gonzáles 1990, Tan 2008, Adogame 2013).

The response which Hauerwas seems to give to these questions is that Christian identity should, first and foremost, be shaped by Christian commitments before any other cultural commitments. He seems to agree with Yoder's critique of Niebuhr that Niebuhr seems to assume that cultures are monolithic (exists as a single bloc that can be accepted or rejected in whole) rather than fractured, and autonomous (valid independent of Christ) rather than having value only within the Christian narrative. For Yoder (1996:54-55, 75), however, the church must be inserted in every context as "a new cultural option" that is distinct from the available cultural options, thereby challenging the view of culture as monolithic and autonomous. ${ }^{3}$ Thus, even though by engaging liberal democratic values Hauerwas' theology has already been determined by an aspect of American culture, his view seems to be that liberal democratic values need to be unmasked as fake, as providing a moral

3 This is also the view of the Ugandan theologian, Emmanuel Katongole, who calls on African Christians to develop a social imagination that presents the "church as a story or set of stories and practices that reflect a different social vision of politics" than the nation state (2004: xv; also see Katongole 2011). 
formation that contradicts Christian values. The place of liberal democratic values should therefore be filled by Christian moral values.

The response in the literature of world Christianity, however, seems to be that Christian identity should first and foremost be shaped by the cultural context in which Christians find themselves. World Christianity therefore does not appear to recognize any specific Christian identity formed by a homogeneous idea of the church or Christianity (given that the culture of the church or Christianity is not monolithic either) but rather many Christian identities formed by different perspectives on the gospel as determined by the local culture. Thus, while Hauerwas presents his position as being in line with Christian orthodoxy, world Christianity sees "orthodoxy" as shifting and negotiable in every context. If orthodoxy is shifting and negotiable it follows that Christian identity may be different in every context. That is partly why world Christianity emphasizes context - thus speaking of Asian Christianity, African Christianity, Latin American Christianity, and so on. While world Christianity does not deny that Christians may have a common identity it appears to emphasize local Christian identities. This paper questions the emphasis placed on local Christian identities, arguing that if not properly balanced by the fact that all people (including Christians) are basically the same, sharing a common humanity, it may engender a global form of Christian apartheid. ${ }^{4}$ The paper will first describe what world Christianity is, give reasons for the focus on the local rather than the universal, and finally problematize the emphasis on the local in the construction of Christian identity in the global context.

\section{What is World Christianity?}

While Christianity has always had a global vision as seen in the mission of the Trinity made manifest in the sending of the Christ and the emergence of the church, the Christian faith has not always been global in nature. While early Christian missionaries took the gospel to many parts of the world, it was only with the modern missionary movement which began after the expansion of Europe in the fifteenth century that the Christian faith was effectively taken to most parts of the world. It was however only in the twentieth century that world Christianity as a field of study began, due to the fact that Western Christian scholars could no longer ignore the fact of the changing demography of the Christian landscape. In the twentieth century many scholars began acknowledging that the Christian faith, which in the Middle Ages and the modern period was dominant in the Northern Hemisphere, was beginning to be, and in fact had become, dominant in the Southern Hemisphere

4 On the issue of balancing the tension between difference and sameness, the particular and the universal, see Schreiter, The New Catholicity, 42-43. 
(Walls 2002; Jenkins 2002). Scholars therefore began to come to terms with what this might portend for the Christian faith. The study of world Christianity therefore became an interdisciplinary project that brought together missiology, intercultural studies, world religions, ecumenics, and globalization (Irvin 2016:3-26; Schreiter 2015:29-43; Johnson 2010: 165-169).

Describing the nature of world Christianity, Lamin Sanneh (2003:22-23) made a now popular but much disputed distinction between world Christianity and global Christianity, seeing global Christianity as the Christianity Western missionaries carried around the world and which, like some depictions of globalization, was based on homogenizing tendencies, and world Christianity as the local appropriation of the faith by various (non-Western) peoples around the world. In other words, world Christianity is made up of the local responses to the Western Christian missionary presentation of the Christian faith as a Western religion (Bediako 1995). Andrew Walls (1996:26-42) has theorized that these local appropriations of the Christian faith are quite legitimate because they fall well within the theological principle of translation, which calls for explicating the salvific nature of a Jewish Messiah to cultures around the world in ways that are familiar to those cultures. He therefore roots the emergence of world Christianity in a Christology that takes seriously the Jewishness of Jesus, noting that when it pleased God to save the world, God did so not in a general or abstract way but in a particular context - the context of Israel and the Jews. Jesus Christ is therefore a translation of divine salvific discourse in a particular context, the context of the Jewish people. Even though this salvific discourse contains a core, he claims, it is and should be infinitely translatable. Christian missions, as Walls saw it, is supposed to be about translating the message of the gospel, to paraphrase the title of the influential work by Lamin Sanneh (2009), in different cultural contexts around the world.

For Walls, at the heart of the world Christian movement, therefore, are the indigenizing and pilgrim principles. The indigenizing principle calls for the Christian faith to be always rooted in particular contexts while the pilgrim principle names the Christian excess that transcends any single context. This excess seems to be what Walls (2002:5-10) sees as the core of the Christian faith, which includes "the worship of the God of Israel . . ., the ultimate significance of Jesus of Nazareth . . .," the belief that "God is active where believers are," and the belief that "believers constitute a people of God transcending time and space." Conversion in this framework does not mean that one is to be uprooted from one's context or culture but rather that one is to be inducted into this new way of life initiated by Jesus Christ within the framework of one's culture. It is in this light that Walls made a distinction between being a convert and being a proselyte. A proselyte was a gentile who followed the way of the Jews by submitting to circumcision and following the Torah. 
In other words, a proselyte was a gentile who became a Jew by being incorporated into Jewish culture. A convert, on the other hand, does not need to be incorporated into Jewish culture; she or he could follow Christ within the framework of her or his own culture - no circumcision and no following of the Torah was necessary (Walls 2002:67-68). A convert was supposed to make the faith their own by following Jesus Christ within their own cultural context. This is why the Christian faith has historically had what may be described as "local colors." As Walls (1996:46) puts it, we receive the gospel "under, and in relation to, the conditions of our experiences and relationships, our environment and society - our culture in fact" (also see Sanneh 2003:41-47). Thus, the Christian faith is necessarily diverse even if it has a core. Even Philip Jenkins, whose influential The Next Christendom (first published in 2002 and revised in 2011) did much to bring the local appropriation of the Christian faith to Western audience, would not commit to only one definition of "what Christians believe," seeing such claims as often occasioned by ignorance of many other manifestations of the Christian faith around the world (2002:3). One may dispute Walls' (or Jenkins') characterization of what may be central or peripheral to the Christian faith but it seems fair to assume that his goal, like Jenkins', is to take seriously the fact of diversity in the Christian faith worldwide. Forced by the reality of the shift of the Christian faith from the global North to the global South, these scholars seem to be alerting the West of the character of the Christian faith in other regions around the world, creating theoretical frameworks within which this shift may be understood.

Even though the whole world is often in view when we speak of world Christianity, the discipline is actually about making the voices of Christians in the non-Western world heard (Sanneh 2008: xxii). Often acknowledged in the study of world Christianity is the fact that the voices of the Christians of the global North have dominated discourses on how the faith is thought about and practiced for a long time. While the voices of Christians in the global North is not dismissed or ignored, the emphasis in the study of world Christianity is placed on the voices of Christians in the "non-Western world" or Christians who are connected to the world "beyond the West" (Phan 2008). Thus, the discipline of world Christianity is born not only out of the realization that Christianity is declining in the global North while it is expanding in the global South but also out of the fact that Christians in the global South are challenging ways of being Christian which Western missionaries took for granted in their transmission of the faith. It is therefore the rise of new cultural voices in the spread of the Christian religion that makes the question of Christian identity central to world Christianity (Johnson 2010). In the history of Christianity, the arrival of new converts from different cultures into the Christian faith has often raised the question of how Christian identity is to be understood. It is no different 
in the present context of world Christianity. As we shall see below, in this context, insisting on local identity is important but at the same time such insistence may be used as a way to exclude, leading to ecclesial and human isolation. In this context, there is therefore a tension between fostering local identities and discerning the universally human or Christian. This tension requires that, in the study of world Christianity, the ethics of identity in general and of Christian identity in particular be constantly raised.

\section{The Question of Identity in World Christianity}

Much of the missionary efforts in the non-Western world took place at a particular moment in the history of the world - a moment of European expansion and domination. In other words, much of the Christianity we have in the non-Western world today is the product of the modern missionary movement which sometimes went hand-in-hand with colonialism. In the case of Africa, for example, colonialism and Christianity were claimed to be ways of civilizing what was believed to be heathen natives. In this context, becoming a Christian meant denying one's African cultural context, for example. In fact, African cultural contexts, characterized by what is today described as African indigenous religions, were sometimes portrayed as demonic and salvation meant being rescued from this demonic context. (Interestingly, this way of viewing the African cultural context is now widespread among many African Pentecostals.) Western missionaries sometimes built what was called mission stations to which some Christian converts moved to live the Christian life - far removed from their relatives who were still seen as wallowing in deep darkness. In this context, therefore, to be a Christian meant to take on a new identity which was completely different from what one had up to the point of conversion. To become a Christian, as one recent influential work referring to a particular brand of African Christianity in our own time has put it, was to "make a complete break with the past" (Meyer 1998) because the past was seen as abhorrent. For many of the new Christians from the background of missionary Christianity, indigenous appropriation of Christianity meant a reassessment of this negative perception of African indigenous cultures to forestall the erasure of cultural memory this may engender.

This tendency to reclaim a people's cultural identity is what Cornel West (1999:119) has described as "the new cultural politics of difference" which critiques "the monolithic and the homogeneous in the name of diversity, multiplicity and heterogeneity." According to West, this new cultural politics of difference has been occasioned by the Age of Europe, the emergence of the United States as the world power, and the decolonization process. While the Age of Europe led to Eurocentrism, the emergence of the United States as a dominant world power led, among other things, to the empowerment of many marginalized voices such 
as those of Jews, women, African Americans, Native Americans, and others (West 1999). These formerly marginalized voices therefore began to reclaim their place in the world by insisting on what makes them different or the same as others. Further, the decolonization process led to the emergence of Third World voices that challenged colonial discourses. ${ }^{5}$ It is in the process of challenging Eurocentrism and colonialism that we begin to see the emergence of world Christianity. As Lamin Sanneh (2003:18) has pointed out, it was actually after colonialism that Christianity began to spread significantly in the non-Western world and the way Christianity was appropriated after colonialism was based on local understanding of the faith, especially initiated by the translation of the gospel into different local languages. The practice and study of world Christianity may therefore be seen as events that emerged in the ferment of massive challenge to dominant and especially Eurocentric discourses.

The contexts in which world Christianity emerged cried out for the reconceptualization of defaced identities. In these contexts, the stress on individual cultural identity appears quite apposite given that not to do so might lead to cultural amnesia and even erasure. After the Age of Europe, the emergence of America as the world power, and decolonization, one may justifiably speak of African Christianity, Asian Christianity, or Latin American Christianity because Christians in these contexts experienced colonial domination. The postcolony, a moment of freedom many had fought and died for, afforded opportunities for identities to be reimagined. The postcolony is a moment in which identities are rethought and new identities forged to account for the colonial history of ignominy (Mbembe 2001; Appiah 1992). In the non-Western world, therefore, the subject of the Christian faith can legitimately be the sometimes-battered identities of the local peoples because the question of identity is critical to how the Christian faith is thought and practiced. Thus, various peoples who live in postcolonial contexts would want to figure out not only what it means to be Christian but also what it means to live as a once conquered people. In fact, the question of their conquest and the ill-treatment of their cultures may form an organizing principle in their appropriation of the faith. Africans, for example, would want to know whether it is correct to claim that they do not have a history, as it was alleged during colonial times, or whether the fact of the matter is rather that their history had been misrepresented and suppressed. They would also want to know whether they do not have a religion as some missionaries claimed or whether in fact their religious life had been misunderstood (Surgitharajah 2005:537). In addition to figuring out what it means to be Christian, it was and is also important to

5 The foregoing claim does not mean that West fails to problematize American imperialism, capitalism, and racial politics. It is rather an acknowledgement of some of the voices that have been enabled by the American moment, despite other vices. 
figure out what it means to be African. In fact, figuring out what it means to be African can legitimately come before figuring out what it means to be Christian because what is at stake and what has been called into question is not one's Christianity but one's being as an African. A similar situation is going on throughout the nonWestern world where local peoples are re-examining narratives that have shaped their identity, including the Christian narrative. Christian identity in these contexts are therefore not only defined by the Christian faith but also by the re-examination of maligned traditional cultures. A double movement would seem to be going on here - a speaking back to what may be considered erroneous descriptions of indigenous cultures and a reimagining of the place of the Christian faith in these cultures. Addressing each of these issues is equally critical.

Hauerwas' critique of Christian ethics in America, namely that its subject matter was and is America, may not quite apply in the non-Western contexts because the way the Christian faith was presented in these contexts called into question the very humanity of the peoples in these places. The process of clarifying an identity that has been maligned, suppressed and repressed, as is currently being done in nonWestern Christianity, is therefore quite justified. In other words, emphasizing local identities in the non-Western world is quite justified because it helps the dominated to begin to reclaim their being in the world as they re-examine their ways of life. As Charles Taylor has argued, recognizing the particular groups to which people belong is critical to enhancing the dignity of both the individual and the group. "Non-recognition or misrecognition," Taylor (1994: 25) writes, "can inflict harm, can be a form of oppression, imprisoning someone in a false, distorted and reduced mode of being." For people to feel a sense of belonging, they need to make sure their identity is clear both internally (to themselves) and externally (to those outside), especially when who they are is constantly under a question mark and the Christian faith often does not unambiguously lift this question mark. When we gain some clarity about such identity, we may begin to see perspectives that might otherwise not be available to us - which is what non-Western Christian voices have done, and are currently doing, to the Christian faith. Non-Western voices are arguing that given that many of them are new to the Christian faith, they had identities before their embrace of this faith. Now that they have embraced the faith, they do not have to jettison who they were before this fact. These voices are now talking about the negotiations that need to take place for the Christian faith to be incorporated into their previous identities. Clarifying how the Christian faith fits in the context of previous identities is therefore a critical endeavor in the context of world Christianity.

The variety of Christian identities that exist today may be seen as a boon to the Christian faith because it allows every group of people to make the faith their own. In this case, the Christian faith becomes a religion that is not forced on people 
(eschewing the past legacy of forcing the religion on some) but one which people freely choose to make their own. Further, the fact that people around the world appropriate the Christian faith differently may be seen as encouraging different ways of mining the various dimensions of the faith, which can hardly be exhausted by just one group of Christians. David Ford, the Cambridge theologian, has described the Christian understanding of salvation as characterized by "unsummarizable richness" and "strongly practical dimension" which "is constantly being adapted to different settings and cultures" (1999:105). Christian groups often focus on one dimension of salvation. While the atonement of the cross has been central to Western Christianity and the union with the triune God in Eastern Christianity, the healing power of the cross has been central to non-Western Christianity, especially in its Pentecostal and Charismatic incarnations. With many different manifestations of the faith, the different dimensions of salvation may be appropriated and each group of Christians could stand as a corrective to the other. It is for this reason that Lesslie Newbigin writes that Western Christianity needs the witness of non-Western Christianity and vice versa (see Walls 2002:69). Different Christian identities may therefore be mutually corrective. However, as the Korean-American theologian Anselm Min argues, in the time of globalization, these different identities do not correct each other if they stay apart from each other but do so if they are in solidarity. Recognizing the tension between the particular and the universal, Min calls for what he describes as the "solidarity of others" where there is "mutual solidarity" among those "who are truly other to one another yet actively cooperate as subjects of a common destiny," because no particular group can experience the fullness of God in isolation (cited in Park 2010:121; also see Min 2004).

Given that particular appropriations of the gospel often focus on just one dimension of the faith, it is also the case that each individual context may seriously undermine the gospel by neglecting its other dimensions. Focusing on what has been described as the prosperity Gospel, for example, may lead a group of Christians to forget the prophetic dimension of the gospel. This is a significant danger, especially with Pentecostalism today. Also, making the Christian faith to feel at home in a particular context may lead a group of Christians to be oblivious to important dimensions of the gospel that may not fit their particular cultures. For example, what is the place of celibacy in an African culture that does not place a premium on it? The place of celibacy in the African context is still to be clearly articulated, especially from a Protestant perspective.

Further, the variety of Christian identities may also serve as an instrument of exclusion and isolation and the creation of ecclesial apartheid. This ecclesial apartheid is not only theologically problematic but also missiologically obstructive. It is theologically problematic because the unity of the body of Christ is something that 
the New Testament seems to see as important to identifying the followers of Christ (John 17:11 and Ephesians 2 and 4:1-6). While the call to unity is not a call to homogeneity, ethnic, ideological, and racial fragmentations clearly do not reflect such unity. Missiologically, what image is a divided church portraying to the world and how is this image conducive to spreading the gospel? It is perhaps for this reason that at the very beginning of his systematic theological reflections, Robert Jenson agonizes over what it means to do theology for a divided church, describing this situation of a divided church as a "radical self-contradiction" (1997:vii). This radical self-contradiction is especially demonstrated in the significant difference in the interpretation of the Bible between most non-Western churches and most churches in the West. An important example of this is the issue of homosexuality which has thrown a wedge between the Anglican Church in Africa and the West (Jenkins 2006).

This radical self-contradiction is also demonstrated in the experiences of nonWestern churches in the West. The recent rise in migration has led to the planting of many non-Western churches in the West (see Padilla and Phan 2015, Adogame 2013). Some of these churches have been planted by African migrants in Europe. These churches do not often see their mission as limited to the conversion of African migrants only but also as directed towards the reconversion of Western societies that were once deeply Christian but are now becoming increasingly secular. While some of these churches have attracted Westerners in large numbers others appear to be immigrant enclaves. As Gerrie ter Haar (2003:261-274) has pointed out in the case of the Netherlands, churches planted by African immigrants in the Netherlands are described as African churches and Dutch people are hardly part of these churches. Even though these churches often describe themselves as international churches that are open to all peoples, most Dutch Christians see them as outside the main form of Christianity in their country. This ethnic description and perception of the church, she finds, is now standing for the racialized categorization that has divided Africans and Europeans in the past. Cultural differences are now standing in the place where racial differences once stood, thus playing into what has been described as a "new racism" (Rattansi 2007:95-102), a form of racism that is based on stressing cultural differences rather than classical racial attributes that have been discredited. By describing the churches founded by African migrants as African churches, the point is to suggest that these churches address the sensibilities of African peoples and so are not suitable for Dutch people who are essentially different from Africans (see Fredericks 2009).

While in actual fact many of the members of these migrant-founded churches are sometimes Africans, Asians, or Latin Americans, as the case may be, this does not mean that these different groups are not, cannot, or should not be open to other 
identities. In fact, they often are open to other identities; they should and must be, open to other identities if Christians are not to live in ecclesial apartheid. Given that world Christianity is emerging at the same time as the phenomenon of globalization, we must come to see that identities and cultures, including Christian identities and cultures, are becoming increasingly crossed. While privileging a variety of identities in the development of world Christianity may be helpful, it is important to ensure that this does not indirectly legitimize racism in ecclesial life, turning back the clock on any progress that has been made in this regard.

It is probably with this in mind that Walls (2002:70) noted that the "greatest issues of twenty-first-century Christianity are likely to be ecumenical," with the quest for friendship among peoples of different Christian perspectives being at the center of Christian ecumenical activities. After all, Jesus said that those who become his disciples have become friends (John 15:13-15), that is, people who care for the well-being of each other and treat each other with dignity and respect because in Christ all are equal (Gal. 3:28). Perhaps a central question in the time of world Christianity is whether such friendship among Christians is possible.

\section{Conclusion}

This paper has argued that the emphasis on particular contexts characteristic of the study of world Christianity is well-founded but must be appropriated with caution if Christians are not to perpetuate the ecclesial apartheid that we currently experience, especially in contexts where Western and non-Western Christianity co-exist. The church should be about the gathering of friends in worship rather than about the sociological differences which modern ethnocentrism and racism have engendered.

\section{References}

Adogame, Afe. 2013. The African Christian Diaspora: New Currents and Emerging Trends in World Christianity. London: Bloomsbury.

Appiah, K. A. 1992. In My Father's House: Africa in the Philosophy of Culture. Oxford: Oxford University Press.

Bediako, K. 1995. Christianity in Africa: The Renewal of a Non-Western Religion. Maryknoll, NY: Orbis Books.

Ford, D. F. 1999. Theology: A Very Short Introduction. Oxford: Oxford University Press. Fredericks, M. 2009. World Christianity: A Training School for Multiculturalism. Exchange 38:3-20.

González, J. L. 1990. Mañana: Christian Theology from a Hispanic Perspective. Nashville: Abingdon Press.

Haar, Gerrie ter. 2003. Who Defines African Identity? A Concluding Analysis. In Uniquely 
African? African Christian Identity from Cultural and Historical Perspectives. Edited by James L. Cox and Gerrie ter Haar. Trenton, NJ and Asmara, Eritrea: Africa World Press, 261-274.

Hauerwas, S. 2015. The Work of Theology. Grand Rapids, MI/Cambridge, UK: Eerdmans. Irvin, D. T. 2016. What is World Christianity? In World Christianity: Perspectives and Insights. Edited by Jonathan Y. Tan and Ahn Q. Tran. Maryknoll, NY: Orbis Books, 3-26.

Jenkins, P. 2002. The Next Christendom: The Coming of Global Christianity. Oxford: 0xford University Press. .2006. The New Faces of Christianity: Believing the Bible in the Global South. Oxford: Oxford University Press.

Jenson, R. W. 1997. Systematic Theology, Volume 1: The Triune God. Oxford: Oxford University Press.

Johnson, T. M. 2010. Globalization, Christian Identity, and Frontier Missions. International Journal of Frontier Missiology 27.4:165-169.

Katongole, E. M. A Future for Africa: Critical Essays in Christian Social Imagination. Scranton: University of Scranton Press. 2011. The Sacrifice of Africa: A Political Theology for Africa. Grand Rapids, MI: Eerdmans.

Kim, S. C. H. ed. 2008. Christian Theology in Asia. Cambridge, UK: Cambridge University Press.

Mbembe, Achille. 2001. On the Postcolony. Berkeley, Los Angeles, London: University of California Press.

Meyer, Birgit. 1998. 'Make a Complete Break With the Past': Memory and Post-colonial Modernity in Ghanaian Pentecostal Discourse. Journal of Religion in Africa 28.3: 316-349.

Min, A. K. 2004. The Solidarity of Others in a Divided World: A Postmodern Theology After Postmodernism. London: T\&T Clark and Bloomsbury.

Niebuhr, H. R. 2001. Christ and Culture. New York, NY: HarperCollins.

Padilla, E. and Peter C. Phan, eds. 2015. Christianities in Migration: The Global Perspective. New York, NY: Palgrave Macmillan.

Park, A. S. 2010. Asian American Theology. In Liberation Theologies in the United States: An Introduction. Edited by Stacey M. Floyd-Thomas and Anthony B. Pinn. New York and London: New York University Press, 115-130.

Phan, P. C. 2008. World Christianity and Christian Mission: Are They Compatible? Insights from the Asian Churches. International Bulletin of Missionary Research 32.4: 193196.

Rajkumar, P., ed. 2015. Asian Theology on the Way: Christianity, Culture, and Context. Minneapolis, MN: Fortress Press.

Rattansi, A. 2007. Racism: A Very Short Introduction. Oxford: Oxford University Press.

Sanneh, L. 2003. Whose Religion is Christianity? The Gospel Beyond the West. Grand Rapids, MI and Cambridge, UK: Eerdmans. 2008. Disciples of All Nations: Pillars of World Christianity. Oxford: Oxford University Press. 
2009. Translating the Message: The Missionary Impact on Culture. Second Edition. Maryknoll, NY: Orbis Books.

Schreiter, R. J. 1985. Construction Local Theologies. Maryknoll, NY: Orbis Books. 1997. The New Catholicity: Between the Global and the Local. Maryknoll, NY: Orbis Books.

. 2015. The Role of Intercultural Hermeneutics in the Understanding of Mission Studies as Intercultural Studies. In Mission for Diversity: Exploring Christian Mission in the Contemporary World. Edited by Elochukwu Uzukwu. Zurich: LIT Verlag, 29-43.

Sugirtharajah, R. S. 2005. Postcolonial Biblical Interpretation. In The Modern Theologians. Edited by David F. Ford. Oxford, UK: Blackwell Publishing, 535-552.

Taylor, C. 1994. The Politics of Recognition. In Multiculturalism: Examining the Politics of Recognition. Charles Taylor et al. Princeton, NJ: Princeton University Press.

Walls, A. F. 1996. The Missionary Movement in Christian History: Studies in the Transmission of Faith. Maryknoll, NY: Orbis Books. 2002. The Cross-Cultural Process in Christian History. Maryknoll, NY: Orbis Book/ T\&T Clark, Edinburgh.

West, Cornel. 1999. The New Cultural Politics of Difference. In The Cornel West Reader. New York, NY: Basic Civitas Books.

Yoder, J. H. 1996. How H. Richard Niebuhr Reasoned: A Critique of Christ and Culture. In Authentic Transformation: A New Vision of Christ and Culture. Edited by Glen $\mathrm{H}$. Stassen, D. M. Yeager, and John Howard Yoder. Nashville, TN: Abingdon Press, 31-90. 